\title{
Systematic revision of the family Pleioplanidae Faubel, 1983 (Polycladida, Acotylea): new genus and combinations
}

\author{
Jorge RODRÍGUEZ ${ }^{1}$, Cristina GRANDE ${ }^{2}$, NataliaVeronica BULNES ${ }^{3}$, Bruno ALMON ${ }^{4}$, \\ Jacinto PEREZ ${ }^{5}$ \& Carolina NOREÑA ${ }^{6, *}$ \\ ${ }^{1,6}$ Departamento de Biodiversidad y Biología Evolutiva, Museo Nacional de Ciencias Naturales \\ (CSIC), c/ Jose Gutiérrez Abascal 2, Madrid 28006, Spain. \\ ${ }^{2}$ Departamento de Biología Molecular and Centro de Biología Molecular "Severo Ochoa" (Consejo \\ Superior de Investigaciones Científicas), Universidad Autónoma de Madrid, 28049 Madrid, Spain. \\ ${ }^{3}$ Universidad Nacional del Sur, Departamento de Biología, Bioquímica y Farmacia, Zoología de \\ Invertebrados I, San Juan 670, 8000 Bahía Blanca, Argentina. \\ ${ }^{4,5}$ Grupo de Estudo do Medio Mariño (GEMM), Puerto Deportivo s/n 15960 Riveira, A Coruña, Spain.
}

$$
\begin{aligned}
& \text { "Corresponding author: norena@mncn.csic.es } \\
& { }^{1} \text { Email: jorge.rodriguezmonter@gmail.com } \\
& { }^{2} \text { Email: cgrande@,cbm.csic.es } \\
& \text { 33Email: vebulnes@criba.edu.ar } \\
& { }^{4} \text { Email: brunoalmon2@yahoo.es } \\
& { }^{5} \text { Email: hydronauta@yahoo.es }
\end{aligned}
$$

${ }^{1}$ urn:1sid:zoobank.org:author:B833502E-CBA4-40CA-AE5A-BAD02F539062
${ }^{2}$ urn:1sid:zoobank.org:author:C8634A50-D3EC-467A-A868-225C231B40F2
${ }^{3}$ urn:Isid:zoobank.org:author:29337810-C92C-4D0B-AC1D-6078DEF42B66
${ }^{4}$ urn:Isid:zoobank.org:author:7C752276-FBC7-4B16-9203-936B1BC46224
${ }^{5}$ urn:Isid:zoobank.org:author:1B36DC0B-C294-4FC7-85CE-1B0C7C658129
${ }^{6} \underline{\text { urn:Isid:zoobank.org:author:DD03B71F-B45E-402B-BA32-BB30343E0D95 }}$

\begin{abstract}
New morphological information, reconsiderations and the first combination of a generic name based on a previously established species are presented in the current revision of the family Pleioplanidae (Polycladida, Acotylea). Species belonging to this family are briefly presented and Laqueusplana bocki gen. et sp. nov. is described. An identification key to all valid species of Pleioplanidae is provided. Furthermore, results from phylogenetic analyses of the species treated herein are discussed.
\end{abstract}

Keywords. Platyhelminthes, flatworms, polyclads, descriptions, key.

Rodríguez J., Grande C., Bulnes N.V., Almon B., Perez J. \& Noreña C. 2017. Systematic revision of the family Pleioplanidae Faubel, 1983 (Polycladida, Acotylea): new genus and combinations. European Journal of Taxonomy 264: 1-30. http://dx.doi.org/10.5852/ejt.2017.264 


\section{Introduction}

The family Pleioplanidae belongs to the superfamily Leptoplanoidea within the suborder Acotylea (Order Polycladida). Faubel (1983) established Pleioplanidae based on the anatomical reconstruction of Notoplana atomata (O.F. Müller, 1776) and the inner organization of its prostatic vesicle, which is divided into numerous tubular chambers that are not directly attached to the central ejaculatory duct. The prostatic vesicle organization of $N$. atomata ("atomata-type") is considered the main apomorphy justifying the formation of Pleioplanidae. Therefore, $N$. atomata was designated as the type species of the family and renamed Pleioplana atomata.

The genus Notoplana Laidlaw, 1903 (Acotylea, Polycladida) is one of the largest and most revised genera of Polycladida. Notoplana, traditionally included within the family Notoplanidae, comprised more than 70 species prior to Faubel's (1983) revision. Following this revision, the genus was reduced to 34 species. As mentioned, one of Faubel's major actions was to combine and delimit a specific group of Notoplana species into the family Pleioplanidae.

Two attempts to reorganize the numerous species of Notoplana were made prior to Faubel (1983). The first attempt was carried out by Bock in 1913 who established three clades: group A with Notoplana evansii Laidlaw, 1903 as the main species, group B based on N. atomata (O.F. Müller, 1776) and group C with N. alcinoi (Schmidt, 1861) as the primary species. Later, Marcus \& Marcus (1966) divided the genus into nine groups of species based on the presence or absence of nuchal tentacles and specific characteristics of the male copulatory system. However, tentacles in preserved specimens may be poorly defined or not visible or recognizable.

The family Pleioplanidae currently comprises 4 genera and 13 species: Pleioplana Faubel, 1983, the largest genus of the family, currently with eight valid species, Melloplana Faubel, 1983 with two species, Izmira Bulnes, 2010 with two species and Persica Maghsoudlou, Bulnes \& Rahimian, 2015 with only one species.

The type species of the family Pleioplanidae, P. atomata, was first described by O.F. Müller (1776) as Planaria punctata, but subsequently designated as Planaria atomata in the original description. Later, Oersted (1844) included Planaria atomata within Leptoplana, but Bock (1913) reassigned this species to the genus Notoplana. Some Notoplana species described during the late nineteenth and the twentieth centuries (Notoplana californica (Plehn, 1898), N. delicata (Yeri \& Kaburaki, 1918), N. mortenseni (Bock, 1913), N. inquieta (Heath \& McGregor, 1912) and N. megala (Marcus, 1952)), were assigned to the genus Pleioplana by Faubel 1983. Recently, P. bosphorensis Bulnes, Kalkan \& Karhan, 2009 and $P$. okusi Bulnes, Kalkan \& Karhan, 2009 were placed in Pleioplana.

Furthermore, the genus Melloplana as described by Faubel (1983) comprises two species previously assigned to the genus Notoplana. Both species, Melloplana ferruginea (Schmarda, 1859) and M. japonica (Kato, 1937), are characterized by the presence of an unarmed male copulatory organ without a stylet. The other two genera of Pleioplanidae are Izmira (I. cinari Bulnes, 2010 and I. turkeyi Bulnes, 2010), which was recently described from the Bosporus (Turkey), and Persica (P. qeshmensis Maghsoudlou et al. 2015) described from the Persian Gulf in Iran.

The description of new genera and species in the family since its establishment in 1983 and the abundance of new morphological information necessitate this current revision. Here, we review known characters, add new characters and perform a phenetic analysis of the family Pleioplanidae, taking into account new combinations and diagnostic features. 


\section{Material and methods}

The examined material includes specimens collected, with the aid of the Grupo de Estudo do Medio Mariño (GEMM), from the north-western coasts of Galicia (Spain), mainly from the Ría de Arousa. Specimens were collected mainly by scuba diving, covering a bathymetric range that extends from the intertidal zone to the maximum accessible depth for scuba diving at approximately 40 metres. Most species were found under stones and rocks or on algal stalks and empty mussel shells, all of which are characteristic habitats for polyclads. Specimens were first photographed in their natural surroundings, then collected by hand using a brush or net and stored in containers according to specimen size. One specimen of Pleioplana atomata found in the intertidal zone at Los Chalanos Beach, Muros de Nalón (Asturias, Spain), was also studied, as were specimens of Pleioplana megala collected from the northern coast of Ubatuba, São Paulo (Brazil), kindly provided by the Swedish Museum of Natural History.

Specimens were first anaesthetized in a 7.5\% magnesium chloride solution, then fixed with temperate Bouin following the Newman \& Cannon method (2003) or placed directly on frozen fixative (Bouin), which causes them to become lethargic and immobile, and thus easily positioned. As the solution melts, specimens become submerged in the fixative. Prior to fixation, a lateral piece of tissue was extracted from each specimen and stored in absolute ethanol intended for future molecular studies.

Specimens were subsequently embedded in paraplast, serially sectioned between 7 and $10 \mu \mathrm{m}$ and stained with AZAN (trichrome staining method). Reconstructions of the internal anatomy were derived from serial sagittal sections. Measurements were obtained from both living and preserved material.

In the present article, the literature was extensively revised. Using morphological information taken from this review and the analysis of new specimens, a list of morphological characters and states was compiled with the Delta software (Dallwitz et al. 1993) to produce a key, update the descriptions and generate the matrix (Table I) used for the phylogenetic analysis.

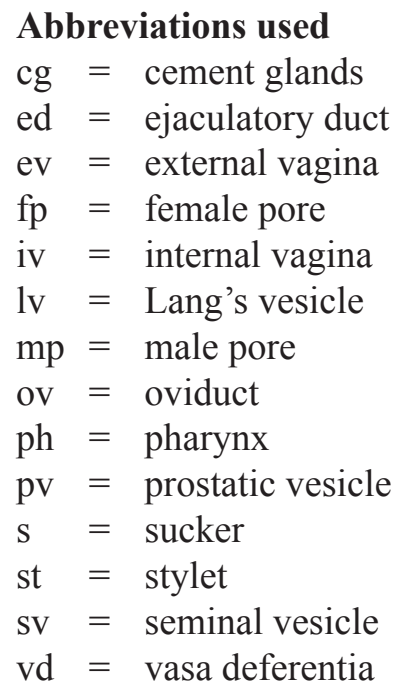

\section{Character list}

1. Body shape: 1. elongated. 2. oval

2. Colour: 1. cryptic. 2. aposematic

3. Dorsal appearance: 1. translucent. 2. opaque

4. Longitudinal median line: 1. not outstanding. 2. highlighted by a concentration of spots

5. Mottled background: 1. absent. 2. homogeneous. 3. heterogeneous 
6. Mottled type with: 1 dots. 2. spots and dots. 3. maculae or patches.

7. Dorsal surface: 1 . smooth. 2. with papillae. 3. with spines

8. Nuchal tentacles: 1. absent. 2. present

9. Tentacular knobs: 1. absent. 2. present

10. Marginal eyes: 1. absent. 2. present on the anterior margin. 3. present around the entire body margin

11. Tentacular eyes: 1 . absent. 2. at the base of or within the tentacles. 3. rounded and compact clusters present instead of tentacles

12. Frontal dorsal eyes (located between the cerebral ganglia and the anterior body margin): 1. absent. 2. in groups of two or four. 3. dispersed. 4. in a fan-like pattern

13. Frontal ventral eyes: 1. absent. 2. in two dense clusters. 3. in four dense clusters

14. Cerebral eyes (located above the cerebral ganglia): 1. absent. 2. in one cluster. 3 . in two clusters. 4 . horseshoe-shaped (both clusters join frontally). 5. a pair of eyes

15. Pharynx: 1. at the end of the first body third. 2. in the second or last body third

16. Pharynx shape: 1 . strongly ruffled. 2 . slightly ruffled

17. Orientation of the pharynx: 1. frontally oriented. 2. ventrally oriented. 3. caudally oriented

18. Oral pore position: 1 . in the first body third and after the cerebral ganglion. 2 . in the first body third and below the cerebral ganglia. 3. in the first body third and before the cerebral ganglion. 4 . in the second body third and in the middle of the pharynx. 5. in the second body third and in the posterior region of the pharynx

19. Intestine: 1. with numerous branches, without anastomosis. 2. with numerous branches and anastomosis; 3. without ramifications

20. Intestinal vesicles: 1 . absent. 2. present

21. Distance between male and female gonopore: 1 . very close to each other (in the same body third). 2 . clearly separated. 3. located in a common pore

22. Male gonopore: 1 . single. 2. double. 3. multiple

23. Male copulatory apparatus: 1 . not enclosed in a muscular bulb. 2. enclosed in a muscular bulb

24. Orientation of male copulatory apparatus: 1. backwards oriented. 2. forward oriented. 3. vertically (dorsal-ventrally) oriented. 4. oriented towards the lateral body sides

25. Location of male copulatory apparatus: 1. in the last body third. 2. in the second body third. 3. in longitudinal rows on either side of the pharynx. 4 . in the first body third (either anterior or posterior to the pharynx)

26. Ejaculatory duct: 1 . with a straight stylet. 2. unarmed, without a stylet (with a penis rod in Izmira). 3. with a spiral-shaped stylet (forming a loop between the prostatic vesicle and the pharynx)

27. Prostatic vesicle: 1. absent. 2. interpolated. 3. free

28. Connection between ejaculatory duct and prostatic vesicle: 1 . with projection. 2. without projection

29. Internal glandular lining of prostatic vesicle: 1. smooth. 2. folded. 3. fingered. 4. ridged. 5. with tubular chambers (of citrus-like appearance in transverse section)

30. Prostatic secretion: 1. intravesicular-epithelial (produced by the lining epithelium). 2. intravesicularmuscular (produced by gland cells in the muscular wall of the vesicle). 3. extravesicular (produced by glands located outside the vesicle and penetrating into the interior of the vesicle by long necks)

31. Prostatic glands: 1. located at the proximal end of the prostatic vesicle. 2. covering the whole prostatic vesicle. 3 . absent

32. Prostatoid organs: 1. absent. 2. present

33. Seminal vesicle shape: 1. simple or spindle-like. 2. tripartite or anchor-shaped

34. Spermiducal bulbs (heavy muscularized ends of the sperm ducts, next to the copulatory apparatus. Accessory seminal vesicles after Lang 1884, Bock 1913): 1. absent. 2. present

35. External (or false) seminal vesicle: 1. absent. 2. present 
36. Vagina: 1. an elongated, tube-like organ, looping towards the male complex. 2. a short tube-like organ directed posteriorly (a short posteriorly directed vagina is a synapomorphy of Cotylea.). 3 . an elongated tube-like organ slanted towards the posterior end of the body

37. Lang's vesicle: 1 . bulbous. 2. enlarged. 3. extending to both sides. 4. absent

38. Uterus: 1. absent. 2. paired. 3. common uterine duct or medial sac

39. Uterine vesicles: 1. absent. 2. one pair of uterine vesicles. 3. multiple uterine vesicles

40. Cement chamber: 1. tube-like. 2. sac-like

41. Genital sucker. 1. absent. 2. present

42. Eggs: 1. ectolecithal. 2. endolecithal

\section{Phylogenetic analysis}

To better understand the evolutionary relationships and observed similarities between the different genera and species of the family Pleioplanidae, a phylogenetic analysis was performed using the following methodology and parameters: optimality criterion = parsimony; bootstrap with heuristic search; number of bootstrap replicates $=1000$; number of characters resampled in each replicate $=45$. Character-status summary of 45 total characters: all are of type "unordered", and all have equal weight. Of these, 19 characters are constant; 6 variable characters are parsimony-uninformative; 20 characters are parsimony-informative; and gaps are treated as "missing". Starting tree(s) obtained via stepwise addition. Addition sequence: simple (reference taxon = Pleioplana atomata; number of trees held at each step $=1$. Branch-swapping algorithm: tree-bisection-reconnection $(\mathrm{TBR})$ with reconnection limit $=$ 8 ; initial 'Maxtrees' setting $=100$; branches collapsed (creating polytomies) if maximum branch length is zero; no topological constraints in effect. Leptoplana tremellaris was designated as the outgroup (Fig. 7).

Also a neighbour joining $(\mathrm{NJ})$ analysis was performed using character-state optimization with accelerated transformation (ACCTRAN).

\section{Results}

\section{Key to the valid pleioplanid species}

1. Ejaculatory duct with a straight stylet and directed backwards ...............................

- Ejaculatory duct unarmed, without stylet and directed backwards .............................

- Ejaculatory duct with a spiral-shaped stylet (forming a loop between the prostatic vesicle and the pharynx) and directed forward ............................................................ 11

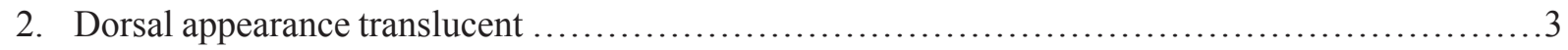

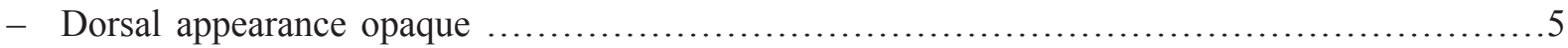

3. Spermiducal bulbs absent; body shape oval ...................Pleioplana okusi Bulnes et al., 2009

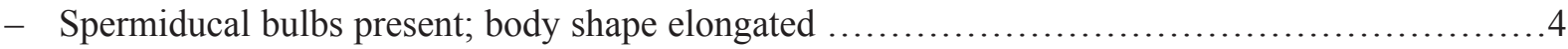

4. Nuchal tentacles absent; tentacular knobs present; tentacular eyes in rounded and compact clusters in place of the tentacles; male copulatory apparatus not enclosed in a muscular bulb; Lang's vesicle present

Pleioplana delicata (Yeri \& Kaburaki, 1918)

- Nuchal tentacles present; tentacular knobs absent; tentacular eyes at the base of or within the tentacles; male copulatory apparatus enclosed in a muscular bulb; Lang's vesicle absent Persica qeshmensis Maghsoudlou et al., 2015

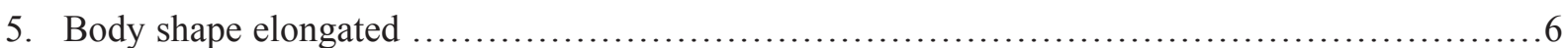

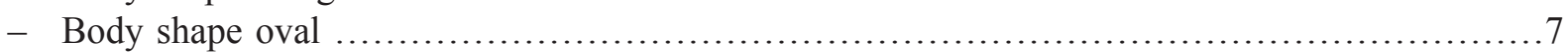


6. Pharynx located at the end of the first body third; spermiducal bulbs present; oral pore in the second body third and in the posterior region of the pharynx; male and female gonopores clearly separated Pleioplana atomata O.F. Müller, 1776

- Pharynx in the second or last body third; spermiducal bulbs absent; oral pore in the second body third and in the middle of the pharynx; male and female gonopores located in a common pore

Pleioplana californica (Plehn, 1898)

7. Spermiducal bulbs absent; connection between ejaculatory duct and prostatic vesicle without projection

Pleioplana mortenseni (Bock, 1913)

- Spermiducal bulbs present; connection between ejaculatory duct and prostatic vesicle with projection .Pleioplana bosphorensis Bulnes, Kalkan \& Karhan, 2009

8. Cerebral eyes absent; spermiducal bulbs present; vagina slanted towards the posterior end of the body

- Cerebral eyes in two clusters; spermiducal bulbs absent; vagina looping towards the male complex

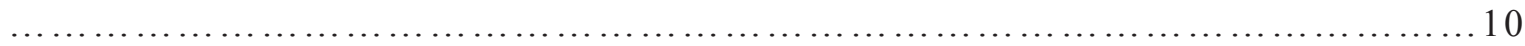

9. Dorsal longitudinal median line not outstanding; oral pore in the second body third and in the middle of the pharynx ...........................Izmira turkeyi Bulnes, Kalkan \& Karhan, 2010

- Dorsal longitudinal median line highlighted by a concentration of spots; oral pore in the second body third and in the posterior region of the pharynx Izmira cinari Bulnes, 2010

10. Male and female gonopores located very close to each other (in the same body third); connection between ejaculatory duct and prostatic vesicle with projection

Melloplana japonica (Kato, 1937)

- Male and female gonopores clearly separated (in different body thirds); connection between ejaculatory duct and prostatic vesicle without projection

Melloplana ferruginea (Schmarda, 1859)

11. Pharynx at the end of the first body third

Laqueusplana bocki gen. et sp. nov.

- Pharynx in the second or last body third ..Laqueusplana megala (Marcus, 1952) comb. nov.

\title{
Taxonomy
}

\author{
Polycladida Lang, 1883 \\ Acotylea Lang, 1884 \\ Leptoplanoidea Faubel, 1983 \\ Pleioplanidae Faubel, 1983
}

\section{Type genus}

Pleioplana Faubel, 1983

\section{Diagnosis}

Pleioplanidae (after Faubel 1983, emended): Leptoplanoidea with varying body outline. Ruffled pharynx arranged centrally or anteriorly. Male copulatory apparatus directed backwards or forwards, posterior to the pharynx. Prostatic vesicle with numerous chambers giving a citrus-like (atomata-type) appearance in cross section. Lang vesicle present or absent. 


\section{Laqueusplana gen. nov. urn:1sid:zoobank.org:act:DFBD1007-F9CA-46D8-8A8A-9827B9045040}

Figs $1-4,6 \mathrm{~A}-\mathrm{B}$

\section{Type species}

Laqueusplana bocki gen. et sp. nov.

\section{Diagnosis}

Pleioplanidae with tentacular and cerebral eye clusters; without tentacles. Male copulatory apparatus directed forward. Seminal vesicle and/or spermiducal bulbs present; penis duct forms a loop between prostatic vesicle and pharynx. Penis stylet long and pointed. Female apparatus usually with vagina bulbosa; Lang's vesicle present.

\section{Etymology}

The name Laqueusplana refers to the term "laqueus", Latin for loop. This is in reference to the loop that the stylet makes between the prostatic vesicle and the pharynx in this genus.

\section{Other species of the genus}

Pleioplana megala (Marcus, 1952) also has a forward directed male copulatory system and shows a loop between the prostatic vesicle and the pharynx. Therefore, it must be transferred to the new genus Laqueusplana gen. nov.

Laqueusplana bocki gen. et sp. nov. urn:1sid:zoobank.org:act:0467FB7F-9254-49E8-AE5F-D02BC2CE89B6

Figs $1-3,6 \mathrm{~A}$

Notoplana atomata O.F. Müller, 1776 in Bock 1913 (partim): 202, table X, fig. 3 (individuals with a spiral-shaped stylet).

\section{Etymology}

The name of the species is dedicated to Sixten Bock, famous Swedish invertebrate zoologist (18841946).

\section{Material examined}

\section{Holotype}

SPAIN: sagittally sectioned, stained with Azan, Jan. 2012 (MNCN 4.01/1118 a 1150, 34 slides).

\section{Paratype}

SPAIN: 1 sagittally sectioned specimen, stained with Azan, among mussels at a depth of nearly 6 meters, Dec. $2013,42^{\circ} 33.7760^{\prime} \mathrm{N}, 08^{\circ} 59.3090^{\prime} \mathrm{W}$ (MNCN 4.01/1151 a 1189, 40 slides).

\section{Type locality}

SPAIN: Galicia, Club Náutico de Riveira, among mussels on a pontoon between half to one meter depth, $42^{\circ} 33.7670^{\prime} \mathrm{N}, 08^{\circ} 59.2860^{\prime} \mathrm{W}$.

\section{Description}

Living worms $25 \mathrm{~mm}$ long and $7 \mathrm{~mm}$ wide. Body shape elongated, of fleshy consistency, broader anteriorly, then stretching to form a slightly pointed posterior end; few smooth marginal undulations (Fig. 1A-C). Dorsal surface with pale beige ground colour and evenly distributed dark brown spots, 

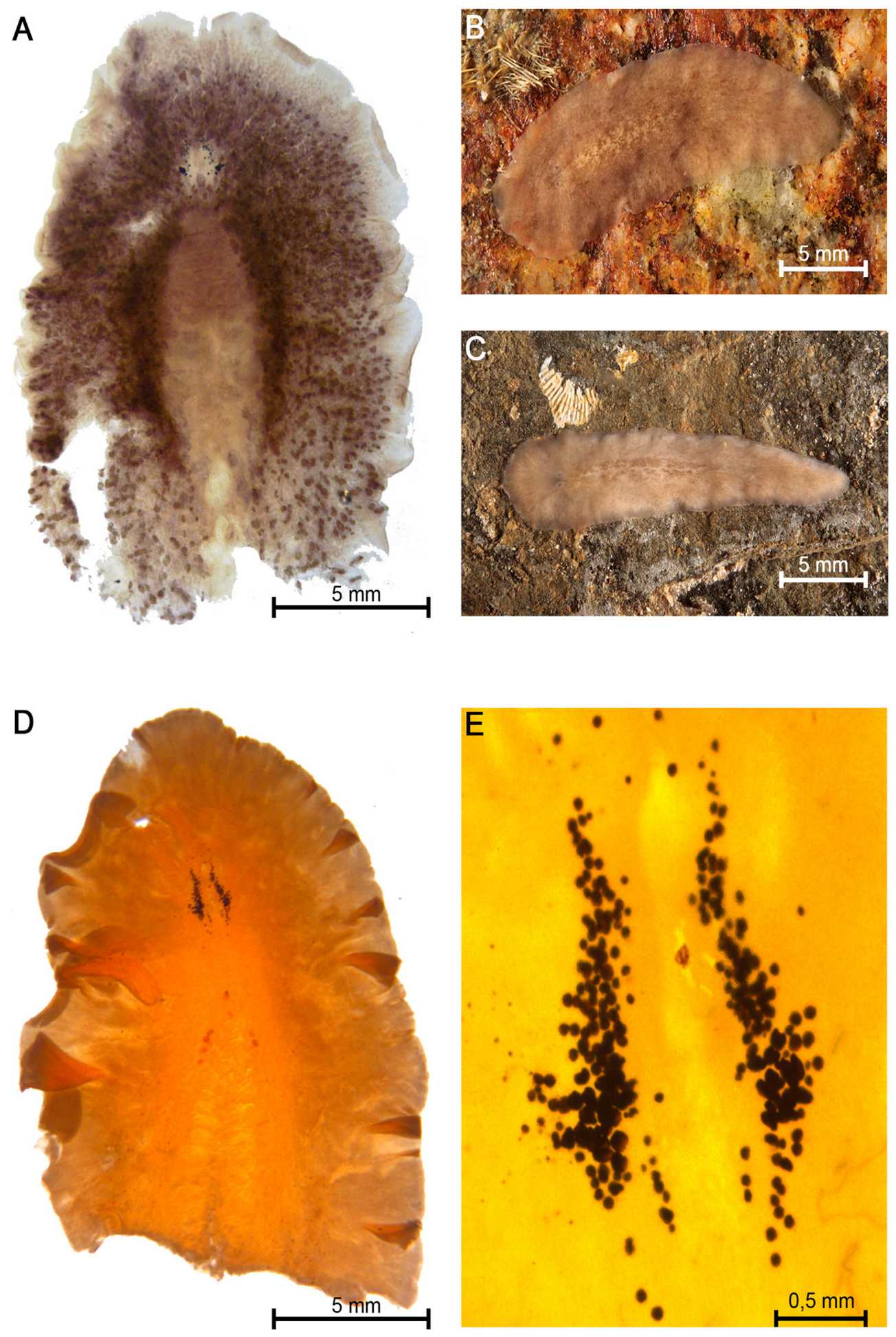

Fig. 1. Species of Laqueusplana gen. nov. A. Dorsal view of a fixed specimen of Laqueusplana bocki gen. et sp. nov. B-C. Dorsal views of living specimens of $L$. bocki gen. et sp. nov. D. Dorsal view of a fixed specimen of L. megala (Marcus, 1952) comb. nov. E. Higher magnification view showing the eye arrangement of L. megala comb. nov. 

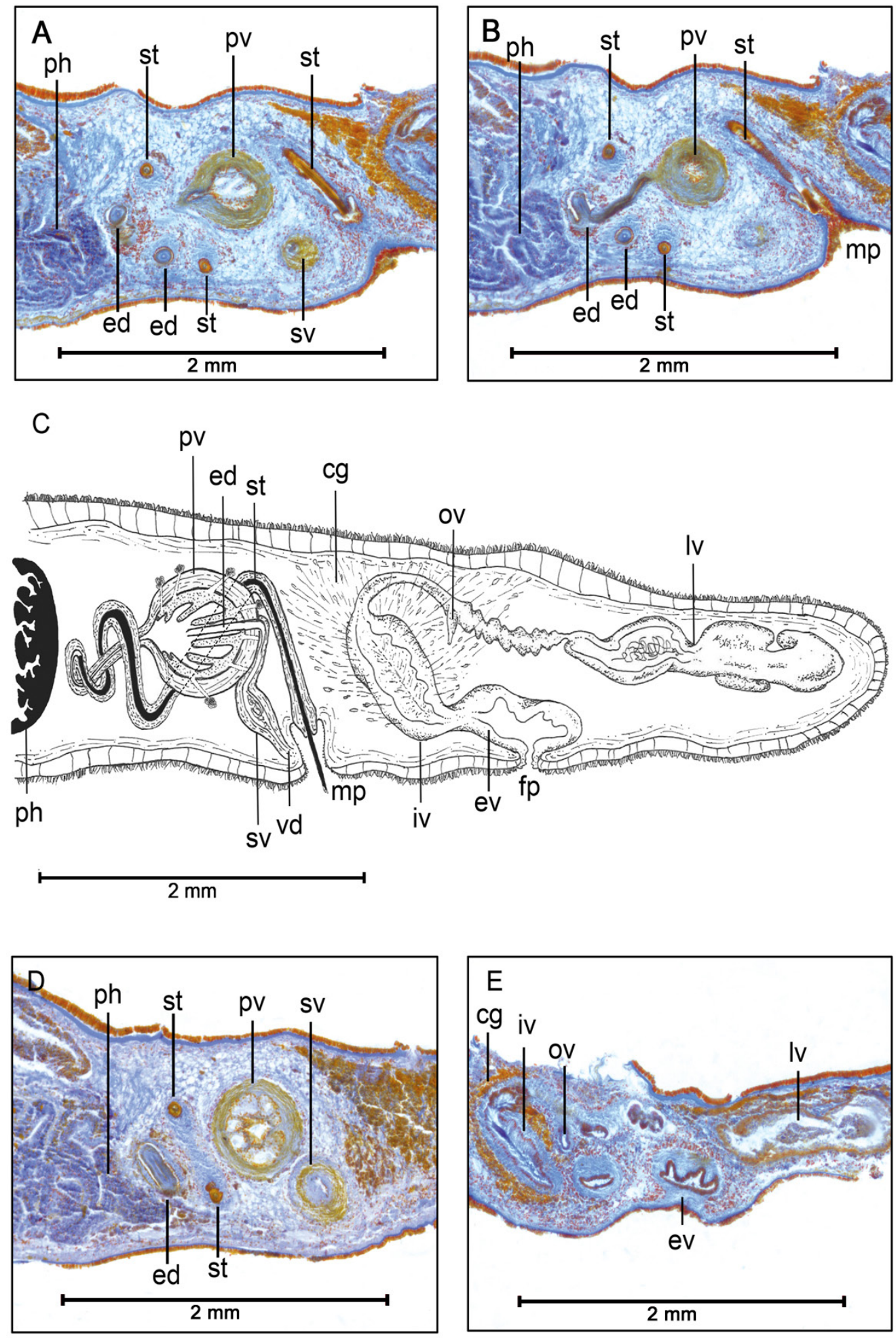

Fig. 2. Laqueusplana bocki gen. et sp. nov. A-B. Histological sections of the reproductive system (anterior end to the left). C. Sagittal reconstruction of the reproductive system. D-E. Histological sections of the male organ. 
except in pharyngeal and genital regions; body margin transparent and spot-free (Fig. 1A). Tentacles absent; instead tentacular eyes present in two rounded clusters. Cerebral eyes form two elongated groups (between 15 and 17 eyes) next to tentacular eyes; marginal or frontal eyes lacking (Fig. 1A). Ventral surface pale brown, almost transparent. Bilobated brain with two symmetrical lobes located ventral to eyes. Pharynx occupies middle third of body, with oral pore opening ventrally in its medial region.
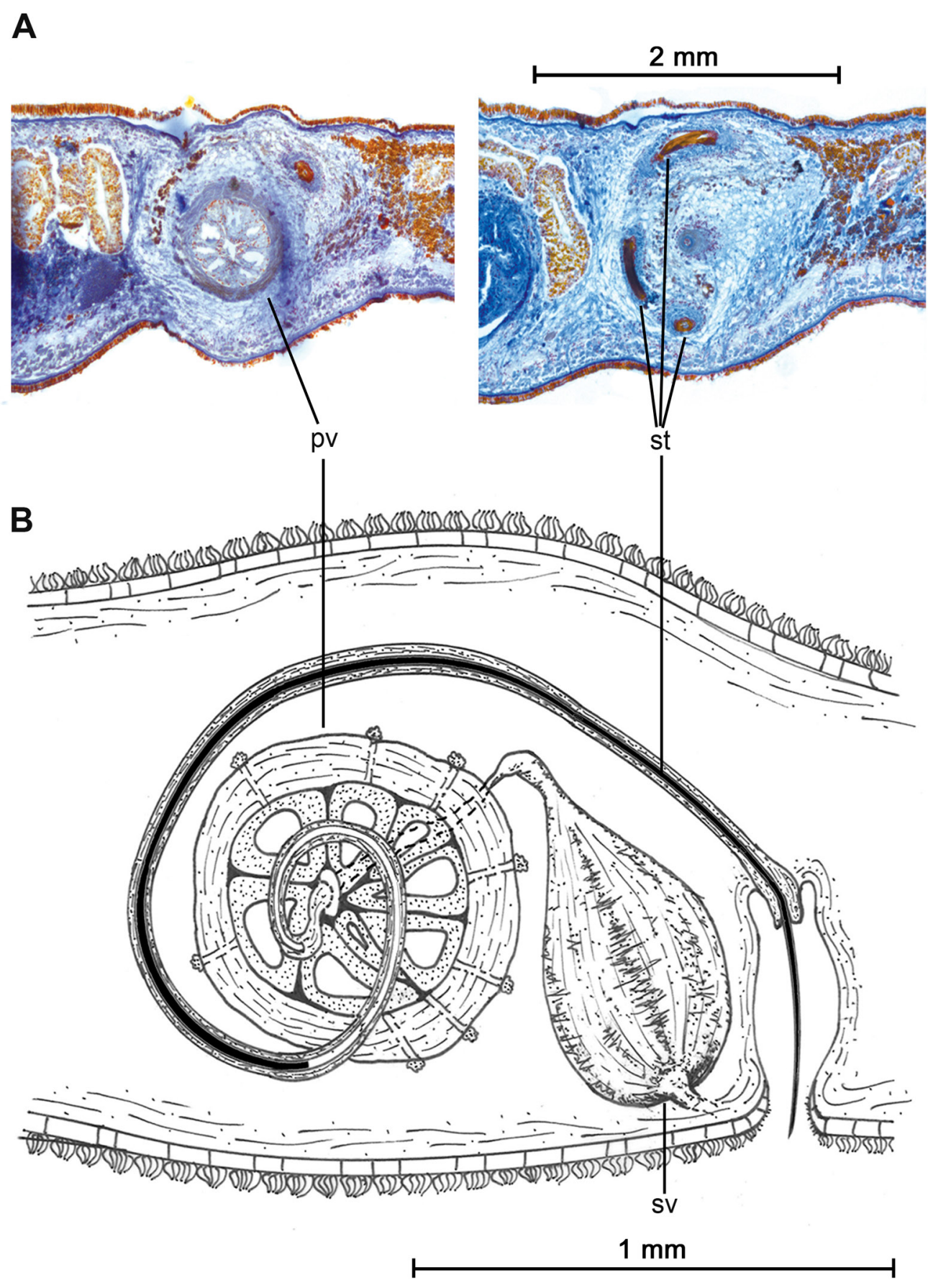

Fig. 3. Laqueusplana bocki gen. et sp. nov. A. Transverse histological sections of the male reproductive organ. B. Transverse reconstruction of the male reproductive system. 
Male and female genital pores well separated, opening at beginning of last third of body. Ovaries well developed, lying dorsally between intestinal branches. Testes ventral.

MALE REPROdUCtIVE SYSTEM. Male copulatory organ consists of an interpolated prostatic vesicle, a true seminal vesicle and a penis papilla with a long, slender stylet, and is located almost immediately behind pharyngeal cavity (Fig. 2C). Testes located ventrally, sometimes observed between intestinal branches. Vasa deferentia run ventrally along both sides of posterior body region, swelling in spermiducal vesicles before entering seminal vesicle proximally. Seminal and prostatic vesicles forward directed (Fig. 2A). Seminal vesicle with thick muscular walls, connected to prostatic vesicle by short and narrow ejaculatory duct (Fig. 2D). Ejaculatory duct projects proximally into prostatic vesicle, crosses it and opens near distal end. Prostatic vesicle oval-shaped, enlarged and covered with strong muscular layers. Prostatic vesicle internally subdivided into at least eight parallel tubular chambers extending from proximal end, giving characteristic citrus-like appearance (Figs 2D, 3A). Extravesicular glands can be found lining proximal end of prostatic vesicle (Fig. 2A). Long coiled stylet emerges from distal end of prostatic vesicle, forms characteristic spiral-like loop between prostatic vesicle and pharynx, turns backwards and opens dorso-ventrally into male atrium (Figs 2A-D, 3). Small conical-shaped penis papilla housed within ciliated atrium (Fig. 2B).

Female ReProductive System. Female system consists of external and internal vaginas, oviducts, uteri and Lang's vesicle (Fig. 2C). Muscular external vagina, or vagina bulbosa, lined with cuboidal epithelium with fringe-like extensions. Vagina bulbosa narrows distally, then extends dorsally or anteriorly towards male copulatory system before reaching internal vagina. Internal vagina turns posteriorly and runs dorsally to posterior end. Oviducts lead separately into common receptacle at proximal end of internal vagina. Numerous shell and cement glands open in region surrounding both vaginas. After receiving oviducts, vagina continues into enlarged Lang's vesicle that extends posteriorly, sometimes reaching posterior end of animal (Fig. 2E).

\section{Differentional diagnosis}

Due to the presence of a prostatic vesicle filled with tubular chambers (atomata-type), separated gonopores and a vagina bulbosa, the genus Laqueusplana gen. nov. belongs to the family Pleioplanidae. However, the presence of a long stylet with a spiral loop and a of forward directed male copulatory system justifies the erection of a new genus within this family.

Species of the genera Izmira Bulnes, 2010, Melloplana Faubel, 1983 and Persica Maghsoudlou et al., 2015 share some characteristics of the Pleioplanidae family, mainly the presence of an atomata-type prostatic vesicle. However, these genera can be differentiated from the genus Laqueusplana gen. nov. et by the following: Izmira lacks cerebral eyes and Lang's vesicle and has a backwards directed male copulatory system and a penis rod; Melloplana is characterized by the presence of an unarmed, muscular penis papilla and Persica presents distinct characteristics such as the presence of nuchal tentacles, a male copulatory organ wrapped in a muscular bulb and an elongated stylet.

Laqueusplana gen. nov. and Pleioplana Faubel, 1983 are morphologically most closely related to each other, which is reflected in a number of shared characteristics. Externally, both have an elongated body with pale ground colour, two clusters of both tentacular and cerebral eyes and lack tentacles. They also possess a ruffled pharynx that occupies the middle third of the body and a copulatory system that begins posterior to the pharynx. Laqueusplana gen. nov., unlike Pleioplana, has the seminal and prostatic vesicles directed forward and a longer, coiled stylet situated between the pharynx and prostatic vesicle.

The female copulatory system of the genus Laqueusplana gen. nov. consists of a well-developed vagina bulbosa and an enlarged Lang's vesicle, which sometimes reaches the posterior end of the animal. In 
general, the female system in this genus is larger than those of other Pleioplanidae genera. Pleioplana and Melloplana show a similar female system as Laqueusplana gen. nov., although smaller in size, while Izmira and Persica present a shorter female track and a complete absence of Lang's vesicle.

\section{Biology}

Live specimens have rapid scrolling movements and, when stressed, are able to swim by rotating the body, orienting the ventral body surface towards the water surface, and shaking the body while waving its edges.

\section{Remarks}

During the study and analysis of Laqueusplana bocki gen. et sp. nov. and similar species we discovered that in the description of Notoplana atomata of Bock (1913: 202), this author mentioned that some individuals in his material showed a long stylet forming a loop. However, in his reconstruction of Notoplana atomata (Bock 1913: 201, fig. 39) this author did not draw a stylet with a loop or a prostatic vesicle directed forward, but he photographed a specimen (Bock 1913: table XX, fig. 3) with these characteristics. This fact means that Bock took note of the outstanding features of the new genus Laqueusplana gen. nov., but probably due to the scarcity of material did not give it any importance and considered the differences as exceptions or artefacts of fixation that did not allow the establishment of new species. Nevertheless, it is clear that of Laqueusplana gen. nov. was present in the study of Bock but it wasn't described; therefore, we dedicate the new species to this great specialist of Polycladida.

\section{Distribution}

Laqueusplana bocki gen. et sp. nov. has only been found along the north-western Atlantic coast of Galicia, Spain. Notably, within the family Pleioplanidae (4 genera and 13 species), Pleioplana atomata (O.F. Müller, 1776) and Laqueusplana bocki gen. et sp. nov. are the only representatives of the family found along European Atlantic coasts. Nonetheless, further research must be done to determine the entire distribution range of the new species.

Laqueusplana megala (Marcus, 1952) comb. nov.

Figs 1, 4, 6B

Notoplana megala Marcus, 1952: 85, figs 154-158.

Pleioplana megala - Faubel 1983: 117.

\section{Examined material}

One mature, sagittally sectioned specimen from the invertebrate collection of the Swedish Museum of Natural History in Stockholm (Sweden), Cat Nr: SMNH 109094 to 109096 (3 slides).

\section{Type locality}

BRAZIL: Island of São Sebastião.

\section{Description}

Body shape elongated. Cryptic colour. Opaque dorsal appearance. Longitudinal median line not outstanding. Without mottled background. Smooth dorsal surface. Nuchal tentacles absent. Tentacular knobs present (Fig. 1D). Marginal eyes absent. Tentacles absent; instead tentacular eyes present in rounded and compact clusters. Dorsal and ventral frontal eyes absent. Cerebral eyes in two clusters (Fig. 1E). Pharynx located in second or last body third, strongly ruffled and ventrally oriented. Oral 

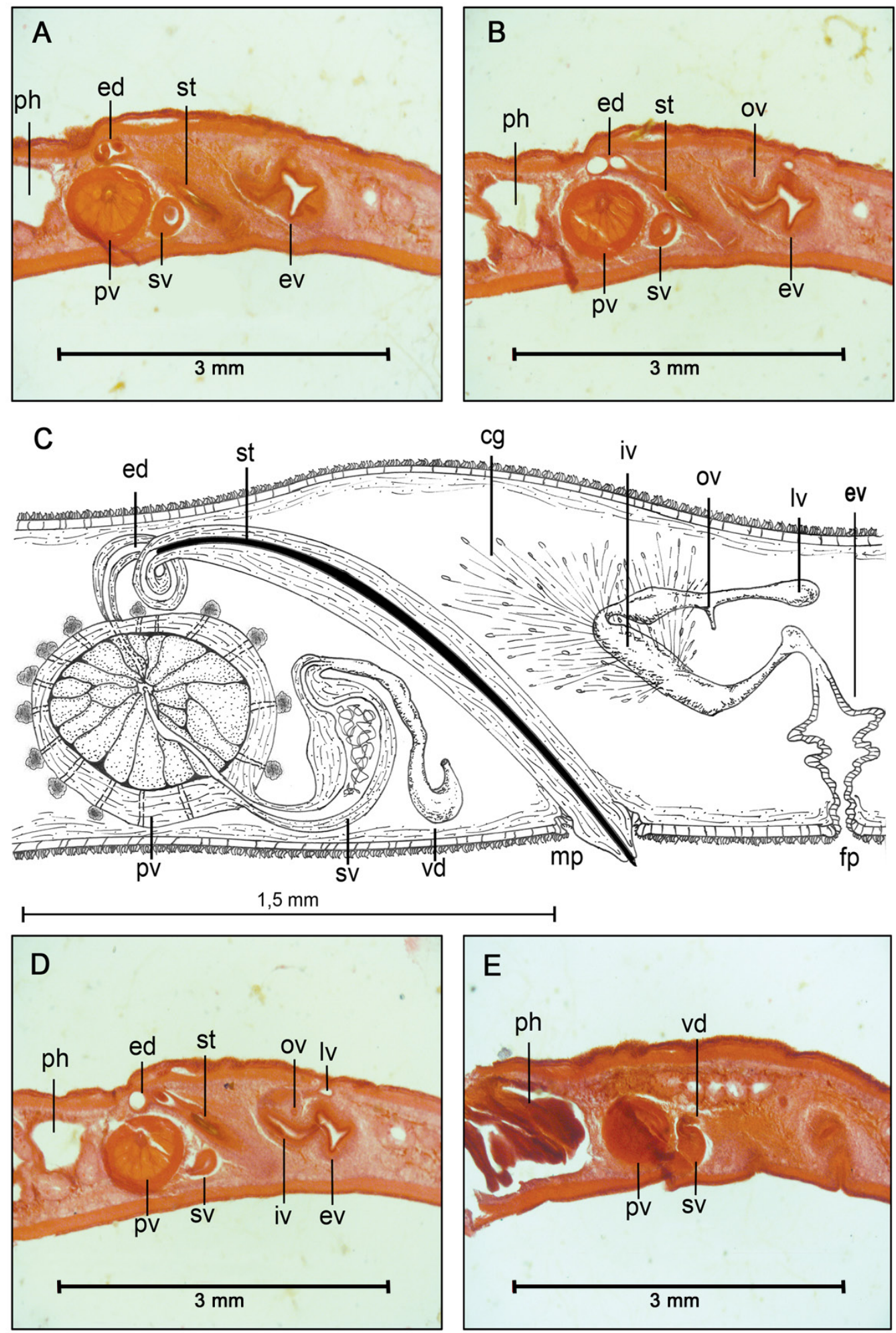

\section{$\mathrm{cg}$}
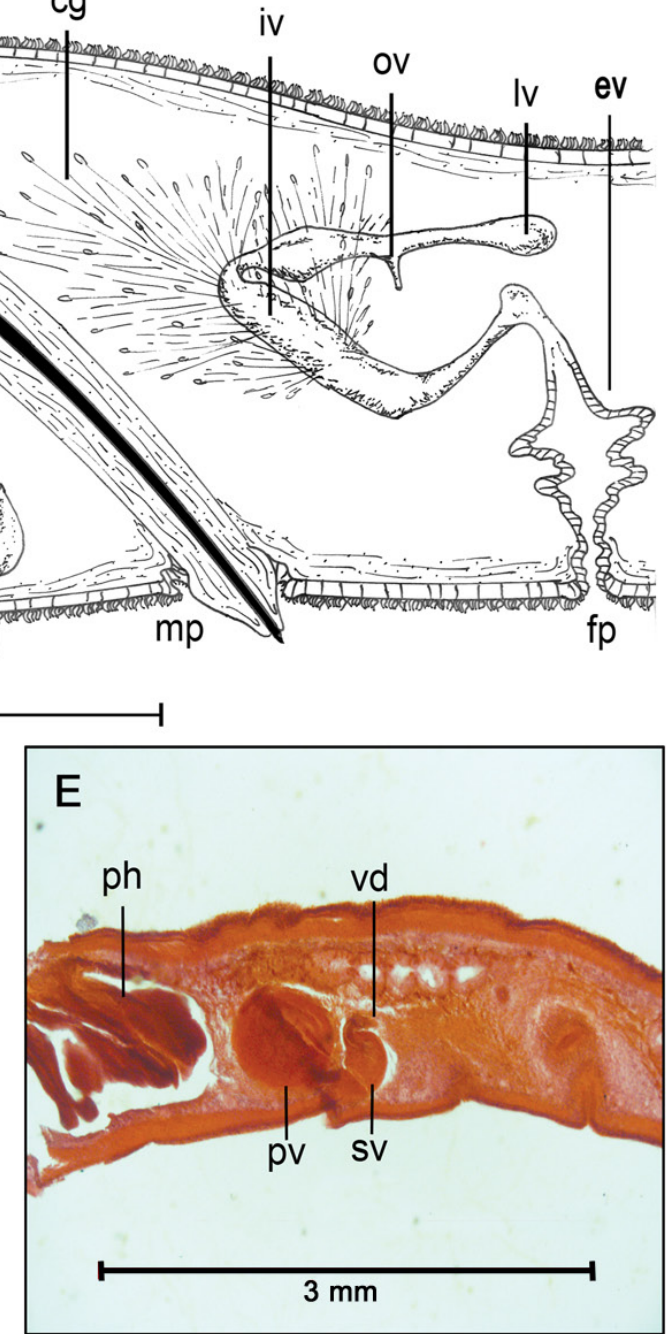

Fig. 4. Laqueusplana megala (Marcus, 1952) comb. nov. A-B. Histological sections of the female reproductive system (anterior end to the left). C. Sagittal reconstruction of the reproductive system. D-E. Histological sections of the male reproductive system (anterior end to the left). 
pore position in second body third and in posterior region of pharynx. Intestine with numerous branches without anastomosis. Intestinal vesicles absent. Gonopores clearly separated.

Male reproductive system (Fig. 4A-E). Single male pore. Male copulatory apparatus not enclosed within muscular bulb, oriented forward and located in last body third. Ejaculatory duct with spiralshaped stylet (forming a loop between prostatic vesicle and pharynx). Prostatic vesicle interpolated. Connection between ejaculatory duct and prostatic vesicle with projection. Internal glandular lining of prostatic vesicle with tubular chambers. Extravesicular prostatic secretion. Prostatic glands located at proximal end of prostatic vesicle. Seminal vesicle simple or spindle-like. Spermiducal bulbs present.

Female ReProductive system (Fig. 4A-D). Vagina elongated, tube-like, looping towards male complex. Bulbous Lang's vesicle. Paired uterus. Uterine vesicles absent. Tube-like cement chamber. Endolecithal eggs.

\section{Biology}

Specimens found on algae from the upper littoral zone.

\section{Distribution}

Ilha de São Sebastião, Ubatuba (São Paulo State), Brazil.

\section{Pleioplana Faubel, 1983}

Fig. $5 \mathrm{~A}-\mathrm{F}$

Pleioplana Faubel 1983: 117, fig. 37A.

\section{Type species}

Pleioplana atomata (O.F. Müller, 1776) (individuals with straight stylets).

\section{Diagnosis}

Pleioplanidae with tentacular and cerebral eye clusters; without tentacles. Male copulatory apparatus directed backwards. Seminal vesicle and/or spermiducal bulbs present. Penis duct continuous with a short (thick or thin) penis stylet. Female apparatus usually with vagina bulbosa; Lang's vesicle present.

\section{Valid species of the genus}

Pleioplana atomata (O.F. Müller, 1776).

Pleioplana mortenseni (Bock, 1913).

Pleioplana delicata (Yeri \& Kaburaki, 1918).

Pleioplana californica (Plehn, 1898).

Pleioplana bosphorensis Bulnes, Kalkan \& Karhan, 2009.

Pleioplana okusi Bulnes, Kalkan \& Karhan, 2009.

Pleioplana atomata (O.F. Müller, 1776)

Fig. 5A

Planaria atomata O.F. Müller, 1776: 37, pl. XXXII, figs 3-4.

Planaria punctata O.F. Müller, 1776: 223.

Leptoplana fallax Diesing, 1840: 198-199.

Leptoplana droebachensis Oersted, 1845: 415.

Polycelis variabilis Girard, 1851: 251.

Planaria maculata Dalyell, 1853: 104-106, pl. IV, figs 27-32. 

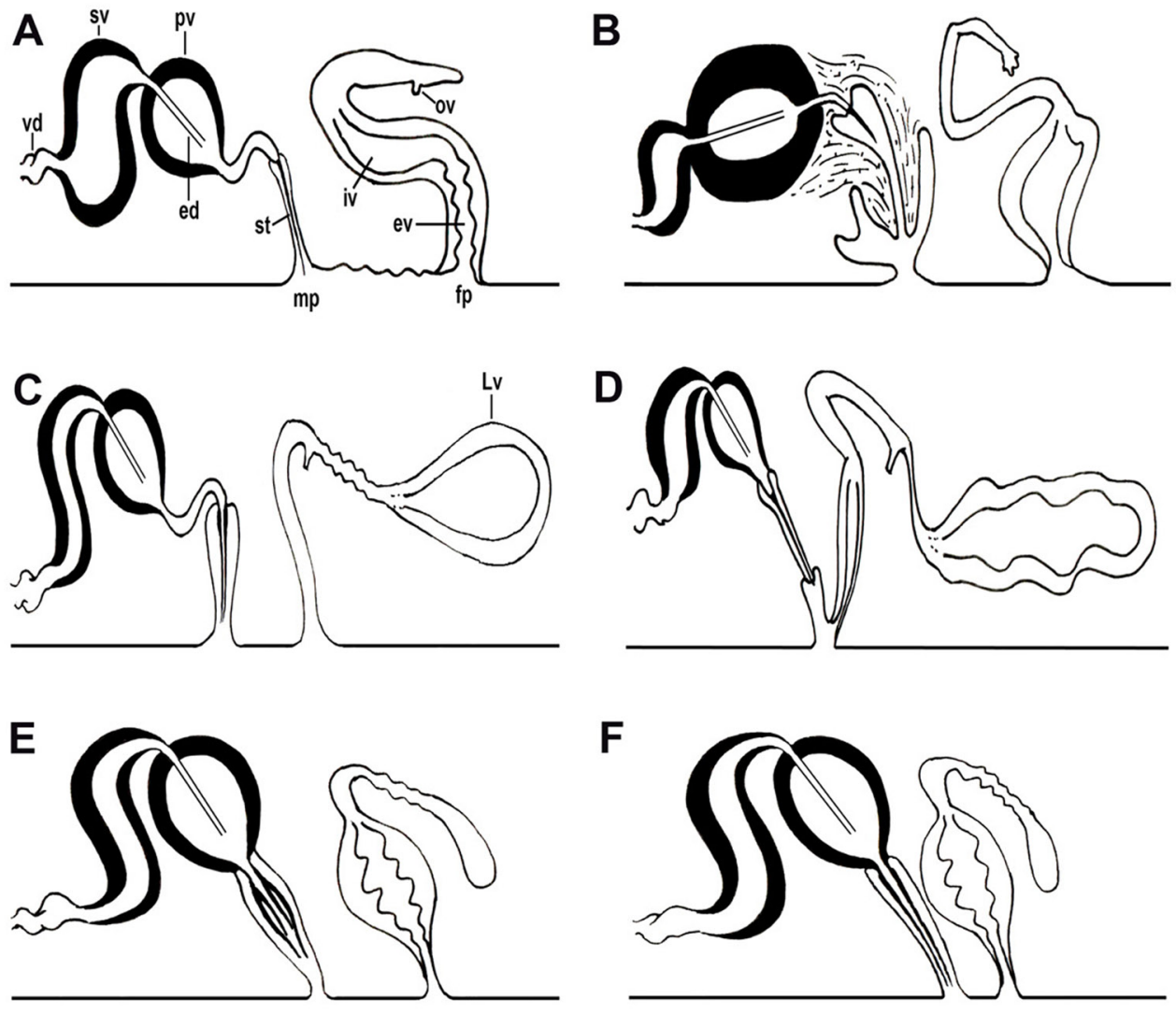

$\mathbf{F}$
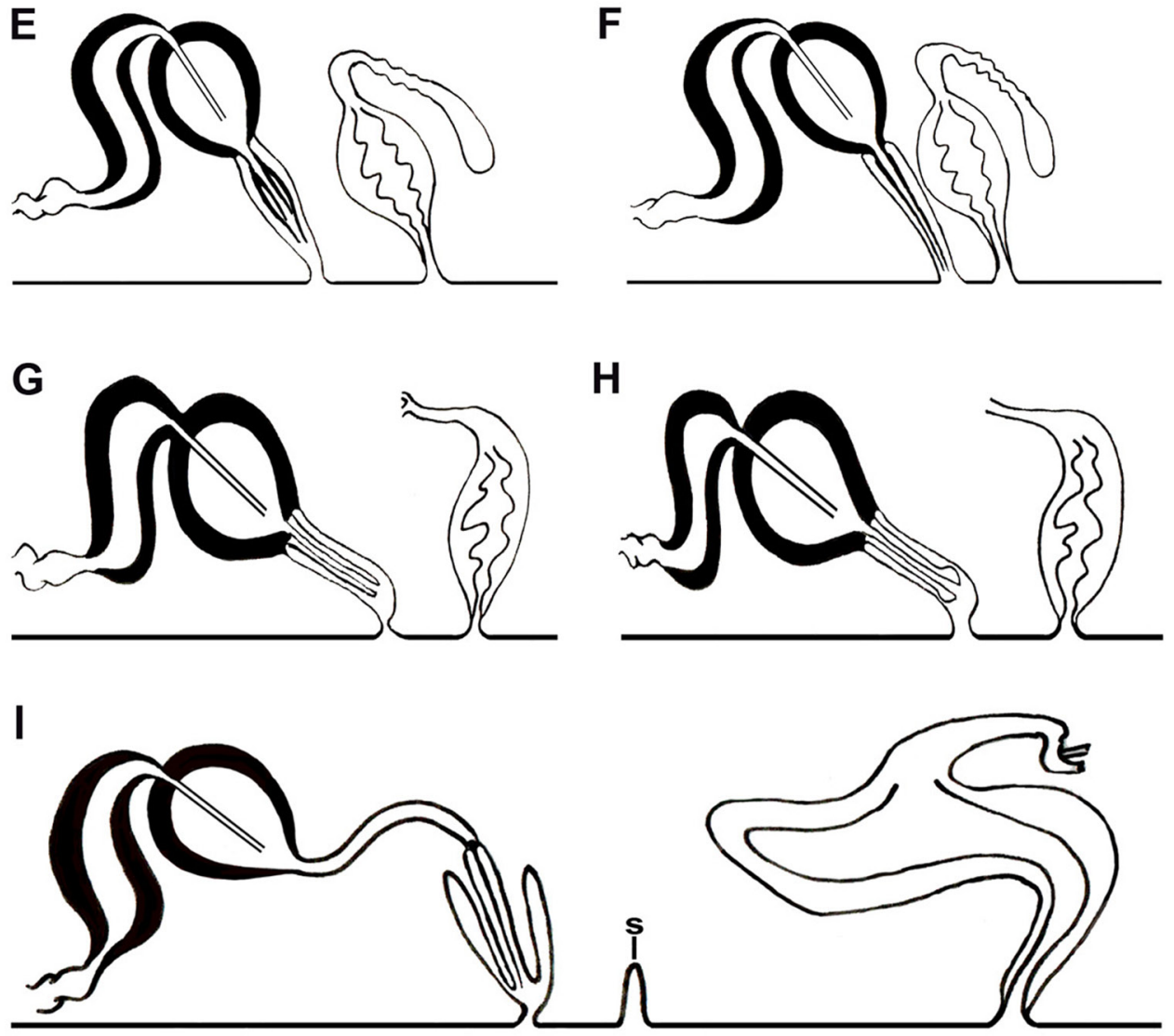

Fig. 5. Schematic representations comparing the copulatory apparatus. A. Pleioplana automata (O.F. Müller, 1776). B. P. mortenseni (Bock, 1913). C. P. delicata (Yeri \& Kaburaki, 1918). D. P. californica (Plehn, 1898). E. P. bosphorensis Bulnes, Kalkan, \& Karhan, 2009. F. P. okusi Bulnes, Kalkan, \& Karhan, 2009. G. Izmira cinari Bulnes, 2010. H. I. turkeyi Bulnes, 2010. I. Persica qeshmensis Maghsoudlou et al. 2015. 
Leptoplana ellipsoides Girard, 1854: 27, table 2, fig. 16.

Leptoplana virilis Verrill, 1893: 478, table 43, figs 1, 1a.

Leptoplana angusta Verrill, 1893: 485, table 40, fig. 8, table 44, figs 2, 2a, 3.

Leptoplana atomata - Oersted 1843: 569; 1844: 49, 79, pl. II, fig. 24. — Leuckart 1847: 149; 1859: 183. — Diesing 1850: 197; 1862: 532. — Maitland 1851: 187-188. — Stimpson 1857: 21. — Johnston 1869: 7. — MacIntosh 1874: 150. — Möbius 1875: 154.

Notoplana atomata - Bock 1913: 195-202, pl. IV, fig. 8, pl. X, figs 3, 6, 8-9.

Planaria atomata - Gmelin 1789: 3091.—Fleming 1823: 297. — Delle Chiaje 1841: 179. — Blainville 1826: 217. — Forbes \& Goodsir 1839: 353. — Johnston 1845: 436.

Pleioplana atomata - Faubel 1983: 117.

Leptoplana droebachensis - Diesing 1862: 526. — Jensen 1878: 76, pl. VII, figs 10-14. — Lang 1884: 494-495.

Notoplana fallax - Bock 1913: 204-205.

Polycelis fallax - Quatrefages 1845: 135, pl. 3, fig. 10, pl. 7, fig. 1, pl. 8, figs 1, 7.

Leptoplana fallax - Stimpson 1857: 31. — Diesing 1862: 533. — Lang 1884: 492. — Vaillant 1890: 654. — Hallez 1893: 166. — Laidlaw 1903: 308.

Leptoplana variabilis - Diesing 1862: 542.

Leptoplana ellipsoides - Stimpson 1857: 27. — Diesing 1862: 533. — Verrill 1874: 43, 45, 132; 1893 : 483, pl. 40, figs 5-6, pl. 42, figs 4, 4 a-b; 1895: 533. — Lang 1884: 512. — Girard 1893: 200, pl. 6, fig. 61. - Whiteaves 1901: 63.

Notoplana virilis - Bock 1913: 208.

Leptoplana angusta - Pearse 1938: 76-77, fig. 26.

\section{Material examined}

One mature, sagittally sectioned specimen deposited in the invertebrate collection of the Museo Nacional de Ciencias Naturales de Madrid (Spain). Cat Nr: MNCN 4.01/763 to MNCN 4.01/834 (72 slides).

\section{Type locality}

NORWAY.

\section{Description}

Body shape elongated. Cryptic colour. Opaque dorsal appearance. Longitudinal median line not outstanding. Heterogeneous mottled background with maculae or patches. Smooth dorsal surface. Nuchal tentacles absent. Tentacular knobs present. Marginal eyes absent. Tentacles absent; instead tentacular eyes present in rounded and compact clusters. Dorsal and ventral frontal eyes absent. Cerebral eyes in two clusters. Pharynx located at end of first body third, strongly ruffled and ventrally oriented. Oral pore position in second body third and in the posterior region of pharynx. Intestine with numerous branches without anastomosis. Intestinal vesicles absent. Gonopores clearly separated.

Male Reproductive system. Single male pore. Male apparatus not enclosed within muscular bulb, oriented backwards and located in last body third. Ejaculatory duct with straight stylet. Prostatic vesicle interpolated. Connection between ejaculatory duct and prostatic vesicle with projection. Internal glandular lining of prostatic vesicle with tubular chambers. Extravesicular prostatic secretion. Prostatic glands located at proximal end of prostatic vesicle. Seminal vesicle simple or spindle-like. Spermiducal bulbs present.

Female Reproductive system. Vagina elongated, tube-like, looping towards male complex. Enlarged Lang's vesicle. Paired uterus. Uterine vesicles absent. Tube-like cement chamber. Endolecithal eggs. 


\section{Biology}

Commonly found along coastal shores, mainly under stones.

\section{Distribution}

Along the northern Atlantic.

Pleioplana mortenseni (Bock, 1913)

Fig. 5B

Notoplana mortenseni Bock, 1913: 192-195, pl. V, fig. 7, pl. VI, fig. 10.

Pleioplana mortenseni - Faubel 1983: 117.

\section{Type locality}

THAILAND: Gulf of Thailand.

\section{Description}

Body shape oval. Cryptic colour. Opaque dorsal appearance. Longitudinal median line not outstanding. Homogeneous mottled background with spots and dots. Smooth dorsal surface. Nuchal tentacles absent. Tentacular knobs present. Marginal eyes absent. Tentacles absent; instead tentacular eyes present in rounded and compact clusters. Dorsal and ventral frontal eyes absent. Cerebral eyes in two clusters. Pharynx located in second or last body third, strongly ruffled and ventrally oriented. Oral pore position in second body third and in posterior region of pharynx. Intestine with numerous branches without anastomosis. Intestinal vesicles absent. Gonopores clearly separated.

Male Reproductive system. Single male pore. Male apparatus not enclosed within muscular bulb, oriented backwards and located in last body third. Ejaculatory duct with straight stylet. Prostatic vesicle interpolated. Connection between ejaculatory duct and prostatic vesicle without projection. Internal glandular lining of prostatic vesicle with tubular chambers. Extravesicular prostatic secretion. Prostatic glands located at proximal end of prostatic vesicle. Seminal vesicle simple or spindle-like. Spermiducal bulbs absent.

Female Reproductive system. Vagina elongated, tube-like, looping towards male complex. Enlarged Lang's vesicle. Paired uterus. Uterine vesicles absent. Tube-like cement chamber. Endolecithal eggs.

\section{Distribution}

Gulf of Thailand.

Pleioplana delicata (Yeri \& Kaburaki, 1918)

Fig. 5C

Notoplana delicata Yeri \& Kaburaki, 1918: 13-15, figs 11-13, pl. II, fig. 14.

Pleioplana delicata - Faubel 1983: 117.

Type locality

JAPAN: Misaki. 


\section{Description}

Body shape elongated. Cryptic colour. Translucent dorsal appearance. Longitudinal median line highlighted by concentration of spots. Heterogeneous mottled background with spots and dots. Smooth dorsal surface. Nuchal tentacles absent. Tentacular knobs present. Marginal eyes absent. Tentacles absent; instead tentacular eyes present in rounded and compact clusters. Dorsal and ventral frontal eyes absent. Cerebral eyes in two clusters. Pharynx located in second or last body third, strongly ruffled and ventrally oriented. Oral pore position in second body third and in posterior region of pharynx. Intestine with numerous branches without anastomosis. Intestinal vesicles absent. Gonopores clearly separated.

Male Reproductive system. Single male pore. Male apparatus not enclosed within muscular bulb, oriented backwards and located in last body third. Ejaculatory duct with straight stylet. Prostatic vesicle interpolated. Connection between ejaculatory duct and prostatic vesicle with projection. Internal glandular lining of prostatic vesicle with tubular chambers. Extravesicular prostatic secretion. Prostatic glands located at proximal end of prostatic vesicle. Seminal vesicle simple or spindle-like. Spermiducal bulbs present.

Female Reproductive system. Vagina elongated, tube-like, looping towards male complex. Enlarged Lang's vesicle. Paired uterus. Uterine vesicles absent. Tube-like cement chamber. Endolecithal eggs.

\section{Biology}

Found along the coast during the low tide.

\section{Distribution}

Shirahama (Prov. Awa), Japan.

\section{Pleioplana californica (Plehn, 1897)}

Fig. 5D

Leptoplana californica Plehn, 1897: 93, table 5, figs 1-2.

Stylochoplana plehni Bock, 1913: 80.

Leptoplana californica - Plehn 1899: 451, fig. B.

Pleioplana californica - Faubel 1983: 117.

Stylochoplana plehni - Hyman 1953: 305.

\section{Type locality}

USA: Monterey Bay, Monterey, California.

\section{Description}

Body shape elongated. Cryptic colour. Opaque dorsal appearance. Longitudinal median line not outstanding. Homogeneous mottled background with spots and dots. Smooth dorsal surface. Nuchal tentacles absent. Tentacular knobs present. Marginal eyes absent. Tentacles absent; instead tentacular eyes present in rounded and compact clusters. Dorsal and ventral frontal eyes absent. Cerebral eyes in two clusters. Pharynx located in second or last body third, strongly ruffled and ventrally oriented. Oral pore position in second body third and in posterior region of pharynx. Intestine with numerous branches without anastomosis. Intestinal vesicles absent. Male and female gonopores located in a common pore.

Male Reproductive system. Single male pore. Male apparatus not enclosed within muscular bulb, oriented backwards and located in last body third. Ejaculatory duct with straight stylet. Prostatic vesicle interpolated. Connection between ejaculatory duct and prostatic vesicle with projection. Internal 
glandular lining of prostatic vesicle with tubular chambers. Extravesicular prostatic secretion. Prostatic glands located at the proximal end of the prostatic vesicle. Seminal vesicle simple or spindle-like. Spermiducal bulbs present.

Female ReProductive system. Vagina elongated, tube-like, looping towards the male complex. Enlarged Lang's vesicle. Paired uterus. One pair of uterine vesicles. Tube-like cement chamber. Endolecithal eggs.

\section{Biology}

Found during low tide between rocks and sand.

\section{Distribution}

California, USA.

\section{Note}

Pleioplana inquieta Heath \& McGregor, 1912, considered synonymous with P. californica by Hyman (1953). According to Hyman, P. inquieta not only shows the same morphological features as $P$. californica, but also shares the same habitat and distribution, namely Monterey Bay, California. Therefore, in this review, $P$. inquieta is considered a synonym of $P$. californica.

Pleioplana bosphorensis Bulnes, Kalkan \& Karhan, 2009

Fig. 5E

Pleioplana bosphorensis Bulnes, Kalkan \& Karhan, 2009: 5-6, figs 1-2.

\section{Type locality}

TURKEY: Altinkum, Bosphorus Strait (Bosphorus).

\section{Description}

Body shape oval. Cryptic colour. Opaque dorsal appearance. Longitudinal median line not outstanding. Homogeneous mottled background with spots and dots. Smooth dorsal surface. Nuchal tentacles absent. Tentacular knobs present. Marginal eyes absent. Tentacles absent; instead tentacular eyes present in rounded and compact clusters. Dorsal and ventral frontal eyes absent. Cerebral eyes in two clusters. Pharynx located in second or last body third, strongly ruffled and ventrally oriented. Oral pore position in second body third and in posterior region of pharynx. Intestine with numerous branches without anastomosis. Intestinal vesicles absent. Gonopores clearly separated.

Male reproductive system. Single male pore. Male apparatus not enclosed within a muscular bulb, oriented backwards and located in last body third. Ejaculatory duct with straight stylet. Prostatic vesicle interpolated. Connection between ejaculatory duct and prostatic vesicle with projection. Internal glandular lining of prostatic vesicle with tubular chambers. Extravesicular prostatic secretion. Prostatic glands located at proximal end of prostatic vesicle. Seminal vesicle simple or spindle-like. Spermiducal bulbs present. External (or false) seminal vesicle absent.

Female Reproductive system. Vagina elongated, tube-like, looping towards male complex. Bulbous Lang's vesicle. Paired uterus. Uterine vesicles absent. Tube-like cement chamber. Endolecithal eggs.

\section{Biology}

Found on a hard bottomed mussel bed of Mytilus galloprovincialis. 


\section{Distribution}

Bosporus Strait, Turkey.

Pleioplana okusi Bulnes, Kalkan \& Karhan, 2009

Fig. $5 \mathrm{~F}$

Pleioplana okusi Bulnes, Kalkan \& Karhan, 2009: 8-9, fig. 3.

\section{Type locality}

TURKEY: Altinkum, Bosphorus Strait (Bosporus).

\section{Description}

Body shape oval. Cryptic colour. Translucent dorsal appearance. Longitudinal median line not outstanding. Heterogeneous mottled background with spots and dots. Smooth dorsal surface. Nuchal tentacles absent. Tentacular knobs present. Marginal eyes absent. Tentacles absent; instead tentacular eyes present in rounded and compact clusters. Dorsal and ventral frontal eyes absent. Cerebral eyes in two clusters. Pharynx located in second or last body third, strongly ruffled and ventrally oriented. Oral pore position in second body third and in posterior region of pharynx. Intestine with numerous branches without anastomosis. Intestinal vesicles absent. Gonopores clearly separated.

Male Reproductive system. Single male pore. Male apparatus not enclosed within muscular bulb, oriented backwards and located in last body third. Ejaculatory duct with straight stylet. Prostatic vesicle interpolated. Connection between ejaculatory duct and prostatic vesicle with projection. Internal glandular lining of prostatic vesicle with tubular chambers. Extravesicular prostatic secretion. Prostatic glands located at proximal end of prostatic vesicle. Seminal vesicle simple or spindle-like. Spermiducal bulbs absent.

Female Reproductive system. Vagina elongated, tube-like, looping towards male complex. Bulbous Lang's vesicle. Paired uterus. Uterine vesicles absent. Tube-like cement chamber. Endolecithal eggs.

\section{Biology}

Found on a hard bottomed mussel bed of Mytilus galloprovincialis.

\section{Distribution}

Bosporus Strait, Turkey.

Izmira Bulnes, 2010

Fig. 5G-H

Izmira Bulnes, 2010: 13-14.

\section{Type species}

Izmira cinari Bulnes, 2010.

Diagnosis (after Bulnes 2010)

Pleioplanidae, oval to elongated, without tentacles. Tentacular eyes present; cerebral, frontal and marginal eyes absent. Male apparatus oriented backwards with a true seminal vesicle, interpolated true citrus-type prostatic vesicle, without stylet and with a penis rod. Female apparatus with vagina bulbosa; Lang's vesicle absent. 


\section{Valid species:}

Izmira cinari Bulnes, 2010.

Izmira turkeyi Bulnes, 2010.

Izmira cinari Bulnes, 2010

Fig. 5G

Izmira cinari Bulnes, 2010: 14, 16, figs 5-6.

\section{Type locality}

TURKEY: Izmir Bay, Aegean Sea.

\section{Description}

Body shape elongated. Cryptic colour. Opaque dorsal appearance. Longitudinal median line not outstanding. Longitudinal median line highlighted by concentration of spots. Smooth dorsal surface. Nuchal tentacles absent. Tentacular knobs present. Marginal eyes absent. Tentacles absent; instead tentacular eyes present in rounded and compact clusters. Dorsal and ventral frontal eyes absent. Cerebral eyes absent. Pharynx located in second or last body third, strongly ruffled and ventrally oriented. Oral pore position in second body third and in posterior region of pharynx. Intestine with numerous branches without anastomosis. Intestinal vesicles absent. Gonopores located very close to each other (in same body third).

Male Reproductive system. Single male pore. Male apparatus not enclosed within muscular bulb, oriented backwards and located in second body third. Ejaculatory duct unarmed, without stylet, but with penis rod. Prostatic vesicle interpolated. Connection between ejaculatory duct and prostatic vesicle with projection. Internal glandular lining of prostatic vesicle with tubular chambers. Extravesicular prostatic secretion. Prostatic glands located at proximal end of prostatic vesicle. Seminal vesicle simple or spindle-like. Spermiducal bulbs present.

Female Reproductive system. Vagina elongated, tube-like and oriented backwards. Lang's vesicle absent. Paired uterus. Uterine vesicles absent. Tube-like cement chamber. Endolecithal eggs.

\section{Biology}

Found in sublittoral mussel beds of Mytilus galloprovincialis.

\section{Distribution}

Bosporus, Aegean Sea, Turkey.

Izmira turkeyi Bulnes, 2010

Fig. $5 \mathrm{H}$

Izmira turkeyi Bulnes, 2010: 17, 20, figs 7-8.

\section{Type locality}

TURKEY: Alsancak Harbour, Izmir Bay, Aegean Sea.

\section{Description}

Body shape elongated. Cryptic colour. Opaque dorsal appearance. Longitudinal median line not outstanding. Homogeneous mottled background with dots. Smooth dorsal surface. Nuchal tentacles 
absent. Tentacular knobs present. Marginal eyes absent. Tentacles absent; instead tentacular eyes present in rounded and compact clusters. Dorsal and ventral frontal eyes absent. Cerebral eyes absent. Pharynx located in second or last body third, strongly ruffled and ventrally oriented. Oral pore position in second body third and in posterior region of pharynx. Intestine with numerous branches without anastomosis. Intestinal vesicles absent. Gonopores located very close to each other (in same body third).

Male Reproductive system. Single male pore. Male apparatus not enclosed within muscular bulb, oriented backwards and located in second body third. Ejaculatory duct unarmed, without stylet, but with penis rod. Prostatic vesicle interpolated. Connection between ejaculatory duct and prostatic vesicle with projection. Internal glandular lining of prostatic vesicle with tubular chambers. Extravesicular prostatic secretion. Prostatic glands located at proximal end of prostatic vesicle. Seminal vesicle simple or spindle-like. Spermiducal bulbs present.

Female Reproductive system. Vagina elongated, tube-like and oriented backwards. Lang's vesicle absent. Paired uterus. Uterine vesicles absent. Tube-like cement chamber. Endolecithal eggs.

\section{Biology}

Found in sublittoral mussel beds of Mytilus galloprovincialis.

\section{Distribution}

Aegean Sea, Turkey.

Persica Maghsoudlou, Bulnes \& Rahimian, 2015

Fig. 5I

Persica Maghsoudlou, Bulnes \& Rahimian, 2015: 5.

\section{Type and only species}

Persica qeshmensis Maghsoudlou, Bulnes \& Rahimian, 2015.

\section{Diagnosis}

Pleioplanidae with tentacular and cerebral eye clusters; with small nuchal tentacles. Male copulatory apparatus directed backwards. Seminal vesicle and/or spermiducal bulbs present. Penis duct continuous with a long penis stylet. Female apparatus usually with vagina bulbosa; Lang's vesicle absent.

Persica qeshmensis Maghsoudlou, Bulnes \& Rahimian, 2015

Fig. 5I

Persica qeshmensis Maghsoudlou, Bulnes \& Rahimian, 2015: 10, 12, figs 2-6, 7a-c.

\section{Type locality}

IRAN: Persian Gulf, Qeshm Island.

\section{Description}

Body shape elongated. Cryptic colour. Opaque dorsal appearance. Longitudinal median line not outstanding. Homogeneous mottled background with dots. Smooth dorsal surface. Nuchal tentacles present, small. Tentacular knobs absent. Marginal eyes absent. Tentacular eyes at base of or within tentacles. Dorsal and ventral frontal eyes absent. Cerebral eyes in two clusters. Pharynx located in second or last body third, strongly ruffled and ventrally oriented. Oral pore position in second body third 
and in posterior region of pharynx. Intestine with numerous branches without anastomosis. Intestinal vesicles absent. Gonopores clearly separated.

Male Reproductive system. Single male pore. Male apparatus enclosed within muscular bulb, oriented backwards and located in second body third. Ejaculatory duct with straight stylet. Prostatic vesicle interpolated. Connection between ejaculatory duct and prostatic vesicle with projection. Internal glandular lining of prostatic vesicle with tubular chambers. Extravesicular prostatic secretion. Prostatic glands located at proximal end of prostatic vesicle. Seminal vesicle simple or spindle-like. Spermiducal bulbs present.

Female ReProductive system. Vagina elongated, tube-like, looping towards male complex. Lang's vesicle absent. Paired uterus. Uterine vesicles absent. Tube-like cement chamber. Endolecithal eggs.

\section{Biology}

Found in the intertidal zone along the Iranian coast of the Persian Gulf.

\section{Distribution}

Iran, Persian Gulf.

\section{Melloplana Faubel, 1983}

Fig. 6C-D

Melloplana Faubel, 1983: 117, fig. 37b.

\section{Type species}

Melloplana ferruginea (Schmarda, 1859).

Diagnosis (after Faubel 1983)

Pleioplanidae with tentacular and cerebral eye-spots; tentacles lacking. Male copulatory apparatus oriented backwards with seminal vesicle, without stylet and with penis papilla. Female apparatus usually with vagina bulbosa. Lang's vesicle present.

\section{Valid species:}

Melloplana ferruginea (Schmarda, 1859).

Melloplana japonica (Kato, 1937).

Melloplana ferruginea (Schmarda, 1859)

Fig. 6C

Polycelis ferruginea Schmarda, 1859: 22, pl. IV, fig. 48.

Discocelis binoculata Verrill, 1901: 43-44, pl. 5, figs 3-4.

Notoplana bahamensis Bock, 1913: 208-210, pl. VI, figs 2-3.

Notoplana caribbeana Hyman, 1939: 2-4, figs 3-8.

Notoplana binoculata - Hyman 1939: 8-10, figs 13-14.

Leptoplana ferruginea - Diesing 1862: 530.

Notoplana ferruginea - Stummer-Traunsfels 1933: 3486, 3521-3522, fig. 60.

Melloplana ferruginea - Faubel 1983: 117. 

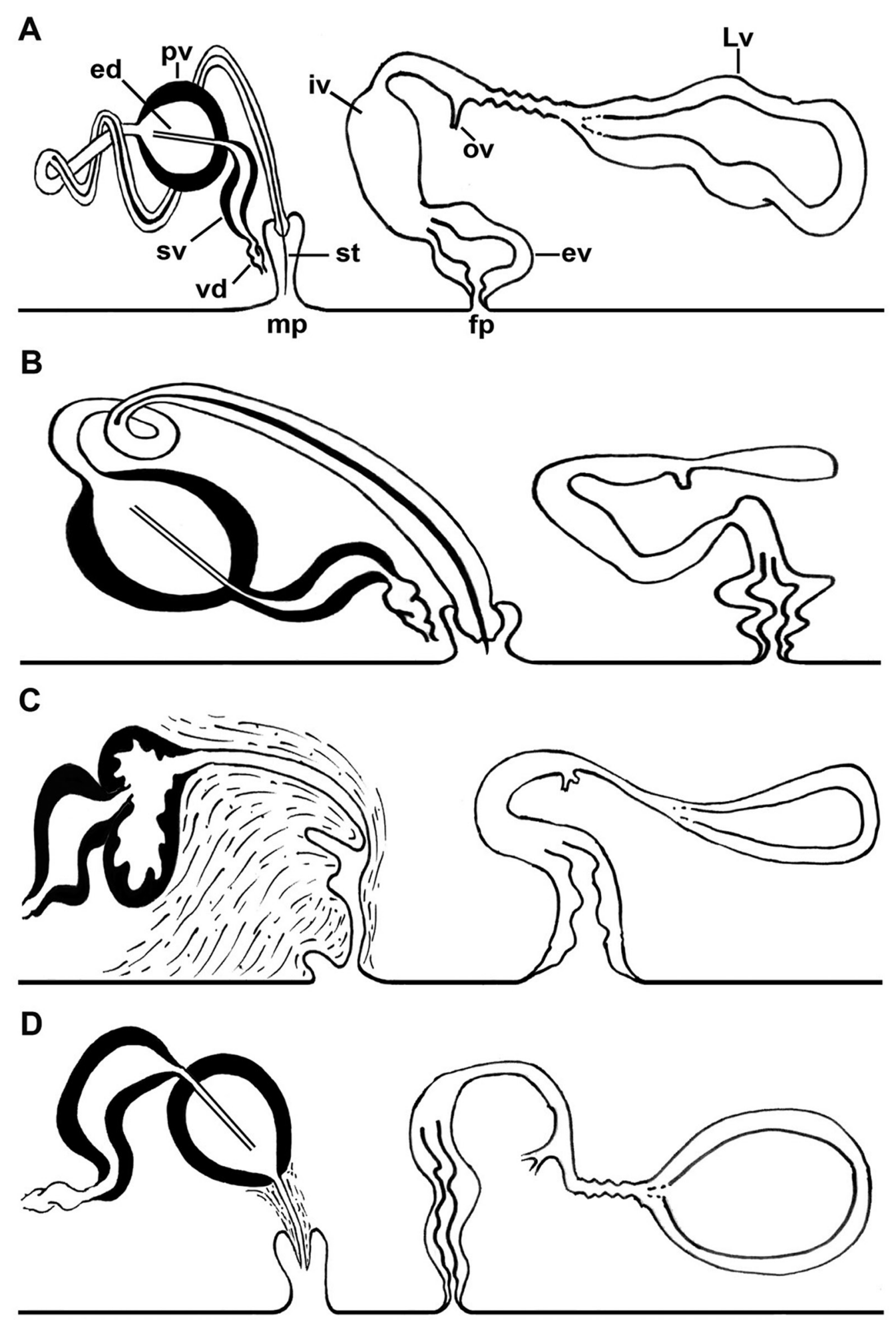

Fig. 6. Schematic representations comparing the copulatory apparatus. A. Laqueusplana bocki gen. et sp. nov. B. L. megala (Marcus, 1952) comb. nov. C. Melloplana ferruginea (Schmarda, 1859). D. M. japonica (Kato, 1937). 


\section{Type locality}

BERMUDA: Long Bird Island.

\section{Description}

Body shape elongated. Cryptic colour. Opaque dorsal appearance. Longitudinal median line not outstanding. Homogeneous mottled background with dots. Smooth dorsal surface. Nuchal tentacles absent. Tentacular knobs present. Marginal eyes absent. Tentacles absent; instead tentacular eyes present in rounded and compact clusters. Dorsal and ventral frontal eyes absent. Cerebral eyes in two groups. Pharynx located in second or last body third, strongly ruffled and ventrally oriented. Oral pore position in second body third and in posterior region of pharynx. Intestine with numerous branches without anastomosis. Intestinal vesicles absent. Gonopores clearly separated.

Male Reproductive system. Single male pore. Male apparatus not enclosed within muscular bulb, oriented backwards and located in second body third. Ejaculatory duct unarmed, without stylet. Prostatic vesicle interpolated. Connection between ejaculatory duct and prostatic vesicle without projection. Internal glandular lining of prostatic vesicle with tubular chambers. Extravesicular prostatic secretion. Prostatic glands located at proximal end of prostatic vesicle. Seminal vesicle simple or spindle-like. Spermiducal bulbs absent.

Female reproductive system. Vagina elongated, tube-like, looping towards male complex. Enlarged Lang's vesicle. Paired uterus. Uterine vesicles absent. Tube-like cement chamber. Endolecithal eggs.

\section{Biology}

Found under stones and on algae, e.g., Halimeda.

\section{Distribution}

Bermuda.

Melloplana japonica (Kato, 1937).

Fig. 6D

Notoplana japonica Kato, 1937: 215-216, figs 5-6, pl. XIV, figs 6-7.

Melloplana japonica - Faubel 1983: 117.

\section{Type locality}

JAPAN: Kanayama (Yuzaki, Yunosaki).

\section{Description}

Body shape elongated. Cryptic colour. Opaque dorsal appearance. Longitudinal median line not outstanding. Without mottled background. Smooth dorsal surface. Nuchal tentacles absent. Tentacular knobs present. Marginal eyes absent. Tentacles absent; instead tentacular eyes present in rounded and compact clusters. Dorsal and ventral frontal eyes absent. Cerebral eyes in two groups. Pharynx located in second or last body third, strongly ruffled and ventrally oriented. Oral pore position in second body third and in posterior region of pharynx. Intestine with numerous branches without anastomosis. Intestinal vesicles absent. Gonopores clearly separated.

Male reproductive system. Single male pore. Male apparatus not enclosed within muscular bulb, oriented backwards and located in second body third. Ejaculatory duct unarmed, without stylet. Prostatic 
vesicle interpolated. Connection between ejaculatory duct and prostatic vesicle with projection. Internal glandular lining of prostatic vesicle with tubular chambers. Extravesicular prostatic secretion. Prostatic glands located at proximal end of prostatic vesicle. Seminal vesicle simple or spindle-like. Spermiducal bulbs absent.

Female Reproductive system. Vagina elongated, tube-like, looping towards male complex. Enlarged Lang's vesicle. Paired uterus. Uterine vesicles absent. Tube-like cement chamber. Endolecithal eggs.

\section{Biology}

Specimens were collected from the undersurface of stones deeply embedded in the sand at low tide during spring and summer.

\section{Distribution}

Japan.

\section{Phylogenetic analysis}

The obtained tree had a length of 55 steps and had the following values: Consistency index $(\mathrm{CI})=$ 0.6000 ; Homoplasy index $(\mathrm{HI})=0.4000 ; \mathrm{CI}$ excluding uninformative characters $=0.5417$; HI excluding uninformative characters $=0.4583$; Retention index $(\mathrm{RI})=0.5510$ and Rescaled consistency index $(\mathrm{RC})=0.3306$.

The recovered topologies from both trees (MP and NJ) support the genus Persica as the sister taxon of all other family members (Fig. 7). In addition, the genera Melloplana, Pleioplana and Laqueusplana gen. nov. group together in a well-supported clade $(\mathrm{BP}=100)$, with Izmira as the sister group of this clade. Furthermore, based on the NJ tree, Pleioplana atomata and the two species belonging to Laqueusplana gen. nov. show greater similarity to the Melloplana species than to the other Pleioplana species.

\section{Discussion}

Following a systematic revision of the family Pleioplanidae, a new genus Laqueusplana gen. nov. is established and described. Laqueusplana gen. nov. is characterized by a very long stylet that forms a spiral-shaped loop and a forward oriented male copulatory organ (likely due to the manner in which the stylet loops). Phylogenetic analyses, used to elucidate the relationship between this new genus and other genera of Pleioplanidae, notably show the early divergence/differentiation of the genus Persica. In contrast to other genera of Pleioplanidae, Persica has nuchal tentacles. In addition, its reproductive system is distinct, having prostatic glands distributed over the entire surface of the prostatic vesicle, a male copulatory organ wrapped in a muscular bulb and an elongated stylet.

The phylogenetic analyses also recovered the two species of the genus Izmira as a monophyletic group, which form the sister group of all the other species of the family, with the exception of Persica. The genus Izmira is differentiated from the other genera by the absence of cerebral eyes, gonopores located closely together, a backwards-directed vagina and an unarmed male copulatory organ with a penis rod.

Our results support a close evolutionary relationship among Pleioplana, Melloplana and Laqueusplana gen. nov. The species of these genera are characterized by, in Pleioplana, the presence of a straight, wide or narrow, stylet, in Melloplana by an unarmed male organ without stylet or rod and in Laqueusplana gen. nov. by a long, spiral-shaped stylet. Although Laqueusplana bocki gen. et sp. nov. and L. megala comb. nov. have previously been described as belonging to the genus Pleioplana, and specifically in the case of L. bocki as $P$. atomata, both Laqueusplana gen. nov. species differ from P. atomata in the length and shape of the stylet and the orientation of the copulatory organ. 


\section{Acknowledgements}

We are deeply indebted to Fernando Ángel Fernández Álvarez for kindly sending Pleioplana atomata material from Asturias. We would also like to thank Dr. Sven Boström from the Swedish Museum of Natural History for loaning us valuable material from their invertebrate collection. This work was supported by the Museo Nacional de Ciencias Naturales (CSIC), funded by project CGL2011-29916 (Ministerio de Ciencia e Innovación) of the Spanish MICINN. We gratefully acknowledge the assistance of the Grupo do Estudo do Medio Mariño (GEMM) members in conducting sampling dives. Finally we

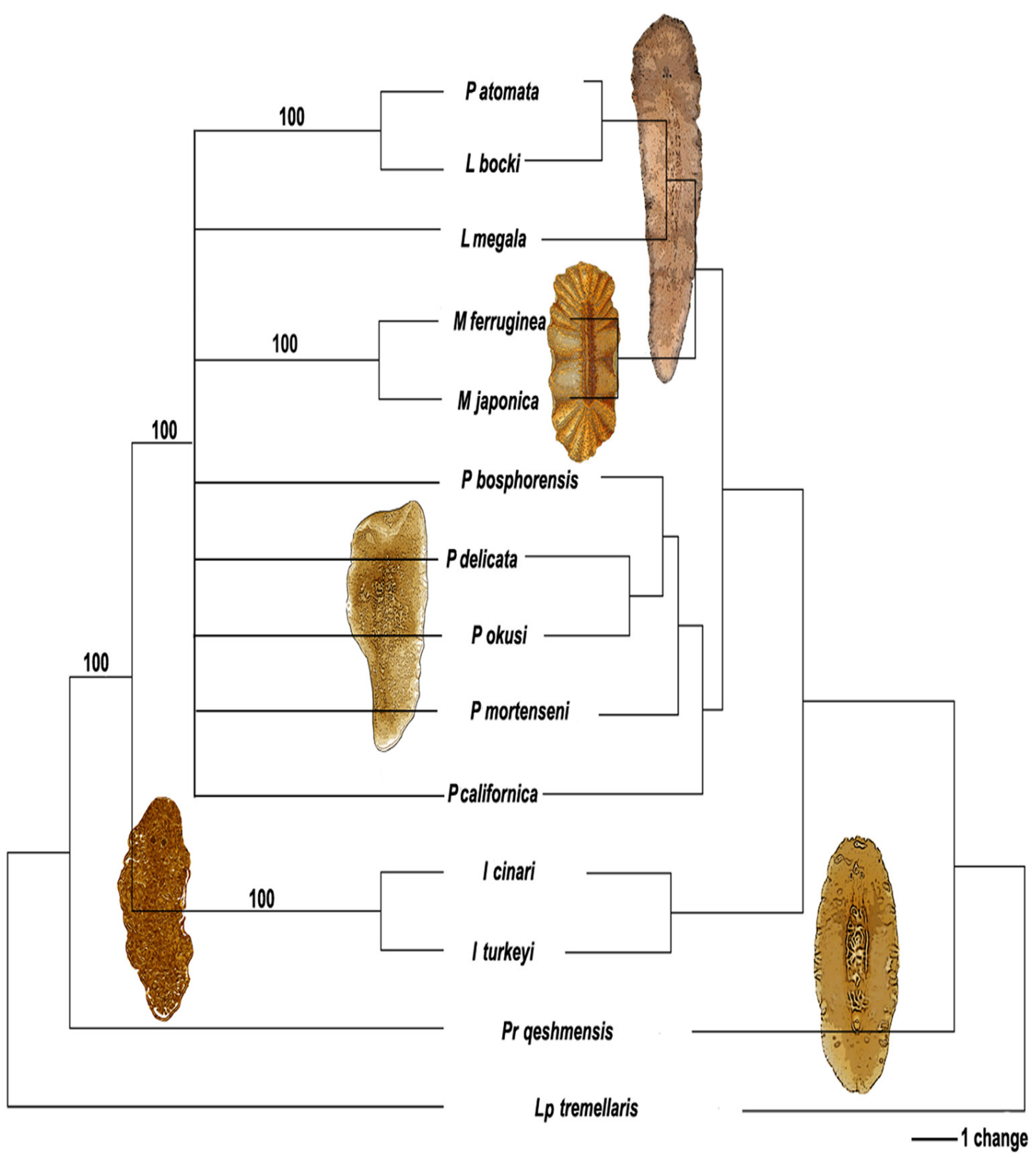

Fig. 7. Maximum parsimony and NJ trees obtained from analyses of Pleioplanidae based on morphological data. The MP tree is shown on the left with bootstrap values indicated at the nodes. The NJ tree is shown on the right. 
would like to thank Melinda Modrell for kindly reviewing the English and the two anonymous reviewers for the careful corrections and valuable comments they made on the manuscript.

\section{References}

Blainville H.M. 1826. Dictionnaire des Sciences naturelles. Planaire. 41: 204-218. F. G. Levrault , Paris 1826.

Bock S. 1913. Studien ueber Polycladen. Zoologiska bidrag från Uppsala 2: 31-344.

Bulnes V.N. 2010. Five new Polycladida (Platyhelminthes: Acotylea) species from the Aegean Sea with remarks on the prostatic structures. Journal of Natural History 44 (9): 515-544. http://dx.doi. org/10.1080/00222930903497535

Bulnes V.N., Kalkan E. \& Karhan S.Ü. 2009. Two new Pleioplana species (Platyhelminthes, Polycladida, Acotylea) from Turkey. Journal of Natural History 43 (37-38): 2273-2281. http://dx.doi. org/10.1080/00222930903094662

Dallwitz M. J., Paine T. A. \& Zurcher E. J. 1993. User's guide to the DELTA System: a general system for processing taxonomic descriptions. 4th edition. Available from http://delta-intkey.com [accessed 12 Jan. 2017].

Delle Chiaje S.1841. Descrizione e notomia degli animali invertebrati della Sicilia citeriore osservati vivi negli anni 1822-1830. Parts 1-8. Batteli \& Co., Naples.

Diesing C.M. 1850 Systema Helminthum. W. Braumüller, Vienna. http://dx.doi.org/10.5962/bhl. $\underline{\text { title. } 46846}$

Diesing K.M. 1862. Revision der Turbellarien. Abtheilung: Dendrocoelen. Sitzungsberichte der Mathematisch-Naturwissenschaftlichen Classe der Kaiserlichen Akademie der Wissenschaften in Wien 44: 485-578. http://dx.doi.org/10.5962/bhl.title.2108

Faubel A. 1983. The Polycladida, Turbellaria; Proposal and establishment of a new system. Part I. The Acotylea. Mitteilungen aus dem Hamburgischen Zoologischen Museum und Institut 80: 17-121.

Fleming J. 1823. Gleanings of Natural History, gathered on the coast of Scotland during a voyage in 1821. Edinburgh Philosophical Journal 8: 297.

Forbes E \& Goodsir J. 1839. Notice of zoological researches in Orkney and Shetland during the month of June 1839. Report of the British Association for Advancement of Science, 9th meeting: 352-353.

Girard C.F. 1893 Recherches sur les planariéns et les némertiens de l'Amerique du Nord. Annales des sciences naturelles (7) Zoologie 15: 145-310.

Gmelin 1789: 3091. Caroli Linné Systema Naturae. Edition 13, volume 1 (part 6): 3021-3910. Lipsiae. http://dx.doi.org/10.5962/bhl.title.36932

Hallez P. 1893 Catalogue des turbellariés (Rhabdocoelides, Triclades et Polyclades) du Nord de la France et de la côte Boulonnaise. Revue biologique du nord de la France 5: 135-158, 165-197.

Heath H. \& McGregor E.A. 1912. New polyclads from Monterey Bay, California. Proceedings of the Academy of Natural Sciences of Philadelphia 64: 455-488.

Hyman L.H. 1953. The polyclad flatworms of the Pacific coast of North America. Bulletin of the American Museum of Natural History 100: 269-391.

Jensen O.S. 1878. Turbellaria ad litora Norvegiae occidentalia. Turbellarier ved Norges Vestkyst. J.W. Eided Bogtrykkeri, Bergen. [in Norwegian]

Johnston 1865. A Catalogue of the British non-parasitical worms: 2-18. London. 
RODRÍGUEZ J. et al., Systematic revision of Pleioplanidae (Polycladida)

Johnston G. 1845. An index to the British annelides. Annals \& Magazine of Natural History 16: 433462.

Kato K. 1937. Polyclads collected in Idu, Japan. Japanese Journal of Zoology 7: 211-232.

Laidlaw F.F. 1903. On a collection of Turbellaria Polycladida from the Straits of Malacca. (Skeat Expedition 1899-1900). Proceedings of the Zoological Society of London 1903: 301-318.

Lang A. 1884. Die Polycladen (Seeplanarien) des Golfes von Neapel und der angrenzenden Meeresabschnitte. Eine Monographie. Fauna und Flora des Golfes von Neapel 11, W. Engelmann, Leipzig. http://dx.doi.org/10.5962/bhl.title.10545

Leuckart R. 1847. Beiträge zur Kenntniss wirbelloser Thiere mit besonderer Berücksichtigung der Fauna des norddeutschen Meeres 4: 149-150. Frey und Leuckart (eds), Braunschweig.

Leuckart R. 1859. Bericht über die Leistungen in der Naturgeschichte der niederen Thiere während des Jahres 1858. Archiv für Naturgeschichte 25 (2): 179-183.

Maghsoudlou A., Bulnes V.N. \& Rahimian H. 2015. Persica qeshmensis gen. et sp. nov. from the Persian Gulf (Platyhelminthes: Polycladida: Acotylea), with remarks on reproductive structures. Journal of Natural History 49 (25-26): 1477-1491. http://dx.doi.org/10.1080/00222933.2015.1006278

Maitland F. 1851. Fauna Belgiae septentrionalis, pars I. Animalia radiata et annulata Cuvieri. LugduniBatavorum 8: 183-190.

Marcus E. 1952. Turbellaria Brasileiros (10). Boletim da Faculdade de Filosofia, Ciencias e Letras Universidade de São Paulo 10: 85-86.

Marcus E. \& Marcus E. 1966. Systematische Übersicht der Polykladen. Zoologische Beiträge 12: 319344.

McIntosh W.C. 1874. On the Invertebrate marine fauna and fishes of St. Andrews. Annals and Magazine of Natural History 4 (19): 144-155.

Möbius F. 1875. Jahresbericht der Commission zur wissenschaftlichen Untersuchung der deutschen Meere in Kiel für die Jahre 1872, 1873, 2. und 3. Jahrgang. Wiegandt, Hempel \& Parey, Berlin.

Müller O.F. 1776. Zoologiae danicae prodromus, seu Animalium Daniae et Norvegiae indigenarum characteres, nomina, et synonyma imprimis popularium. Hallageriis, Havniae [Copenhagen].

Newman L. \& Cannon L. 2003. Marine Flatworms: The World of Polyclads. CSIRO Publishing, Australia.

Oersted A.S. 1843. Forsøg til en ny Classification of Planarierne (Planariea Dugés) grundet paa mikroskopish-anatomiske Undersøgelser. Kroyer's Naturhistorisk Tidsskrift (I) 4 (8): 519-581.

Oersted A.S. 1844. Entwurf einer systematischen Einteilung und speziellen Beschreibung der Plattwuermer auf microscopische Untersuchungen gegruendet. [I. Fam. Cryptocoela, 2. Fam Dendrocoela, 3. Fam. Rhabdocoela]. J.C. Scharling, Copenhagen.

Pearse A.S.1938. Polyclads of the East Coast of North America. Proceedings of the United States National Museum 86: 67-97.

Plehn M. 1897. Drei neue Polycladen. Jenaische Zeitschrift 31 (N.F. 24): 90-99.

Quatrefages A. 1845. Études sur les types inférieurs de l'embranchement des annelés: mémoire sur quelques planairées marines appartenant aux genres Tricelis (Ehr.), Polycelis (Ehr.), Prosthiostomum (Nob.), Proceros (Nob.), Eolidiceros (Nob.), et Stylochus (Ehr). Annales des Sciences Naturelles (3) Zoologie 4: 129-184. 
Schmarda L.K. 1859. Neue wirbellose Thiere beobachtet und gesammelt auf einer Reise um die Erde 1853 bis 1857. Bd I: Turbellarien, Rotatorien und Anneliden. W. Engelmann, Leipzig. http://dx.doi. org/10.5962/bhl.title.85313

Stimpson W. 1857. Prodromus descriptionis animalium evertebratorum, quae in Expeditione ad Oceanum Pacificum Septentrionalem a Republica Federata missa, Johanne Rodgers Duce, observavit et descripsit. Pars I, Turbellaria Dendrocoela. Proceedings of the Academy of Natural Sciences of Philadelphia 9: $19-31$

Vaillant L. 1890. Histoire naturelle des Annelés marins et d'eau douce. Lombriciens, Hirudiniens, Bdellomorphes, Térétulariens et Planariens 3 (2): 621-656. Librairie encyclopédique de Roret, Paris.

Verrill A.E. 1874. Results of recent Dredging Expeditions on the coast of New England. American Journal of Science and Arts 3 (7): 38-46, 132-138.

Verrill A.E. 1893. Marine planarians of New England. Transactions of the Connecticut Academy of Arts and Sciences 8: 459-520.

Verrill A.E. 1895. Supplement to the marine nemerteans and planarians of New England. Transactions of the Connecticut Academy of Arts and Sciences 9: 523-534.

Whiteaves J.F. 1901. Catalogue of the Marine Invertebrata of Eastern Canada. Geological Survey of Canada 722, Ottawa. http://dx.doi.org/10.5962/bhl.title.64454

Yeri M. \& Kaburaki T. 1918. Description of some Japanese Polyclad Turbellaria. Journal of the College of Science, Tokyo Imperial University 39 (9): 1-54.

Manuscript received: 30 March 2016

Manuscript accepted: 12 July 2016

Published on: 25 January 2017

Topic editor: Rudy Jocqué

Desk editors: Jeroen Venderickx and Kristiaan Hoedemakers

Printed versions of all papers are also deposited in the libraries of the institutes that are members of the EJT consortium: Muséum national d'Histoire naturelle, Paris, France; Botanic Garden Meise, Belgium; Royal Museum for Central Africa, Tervuren, Belgium; Natural History Museum, London, United Kingdom; Royal Belgian Institute of Natural Sciences, Brussels, Belgium; Natural History Museum of Denmark, Copenhagen, Denmark; Naturalis Biodiversity Center, Leiden, the Netherlands. 